\title{
Population dynamics and habitat preference of two urbanized Columbidae species and their nest predator in two settlement types
}

\author{
Sámuel Zsolt VARGA* \& Lajos JuHÁsZ
}

Received: July 10, 2020 - Revised: October 14, 2020 -Accepted: October 16, 2020

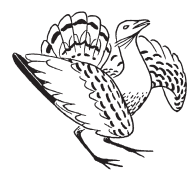

Varga, S. Zs. \& Juhász, L. 2020. Population dynamics and habitat preference of two urbanized Columbidae species and their nest predator in two settlement types - Ornis Hungarica 28(2): 146-157. DOI: 10.2478/orhu-2020-0023

\begin{abstract}
Since urbanization is a worldwide phenomenon, numerous species have gained the advantage of urban ecosystems. The Eurasian Collared Doves (Streptopelia decaocto) has become widespread all across Europe along with human-altered habitats. In general, population levels are stable but numbers have locally decreased in the past few decades. In parallel, a new wave of urbanization came forward, so Wood Pigeons (Columba palumbus) entered urban ecosystems alongside with other Columbidae species. In this paper, our primary goal was to find any connection between habitat availability factors such as coniferous tree density and the population dynamics of two urbanized species. A locally emerging corvid species, the Hooded Crow (Corvus cornix) was also taken into consideration in influencing tree-nesting doves and pigeons as a primary nest predator. During the research period, we aimed to express the differences in habitat structure of two urban ecotypes by nesting tree availability and structure and to prove the power of predator presence in sampling sites. Our results showed that residential areas have a higher proportion of coniferous trees, as well as the high preference of residential areas by Wood Pigeons and Eurasian Collared Doves.
\end{abstract}

Keywords: urbanization, Eurasian Collared Dove, Wood Pigeon, Hooded Crow, coniferous tree-availability

Összefoglalás Az urbanizáció egy világszerte zajló folyamat, mely során egyes fajok előnyt kovácsoltak a városi ökoszisztéma nyújtotta lehetőségekböl. Így lett a balkáni gerle (Streptopelia decaocto) Európa-szerte széleskörüen elterjedt kultúrakövető faj, amelynek állománya összességében stabil, azonban vannak olyan kisebb régiók, ahol állományuk csökkenő tendenciát mutat. Ezzel párhuzamosan az örvös galamb (Columba palumbus) fokozatosan erősödő városi térnyerése is megfigyelhetö. Jelen kutatás célja, hogy a városi élőhely nyújtotta adottságok, valamint a két galambfaj állománydinamikája közötti kapcsolatokat feltárja. A populációt befolyásoló tényezők közé bekerült a helyi szinten megerősödő dolmányos varjú (Corvus cornix) populációja is, mint elsődleges fészekpredátor. A kutatás során két különböző településtípus fenti fajokra gyakorolt hatását kívántuk megismerni, ezzel egyidejủleg a ragadozók állományszabályozó erejét is bizonyítani. A két városi élöhelytípus között jelentős különbségek voltak tapasztalhatók a fafajkínálat és a populációsűrüség értékei között egyaránt.

Kulcsszavak: városökológia, balkáni gerle, örvös galamb, dolmányos varjú, tülevelü fafaj-készlet

Department of Nature Conservation Zoology and Game Management, University of Debrecen, Faculty of Agricultural and Food Sciences and Environmental Management, 4032 Debrecen, Böszörményi út 138., Hungary

* corresponding author, e-mail: varga.samuel@agr.unideb.hu 


\section{Introduction}

Urbanization is a common phenomenon that changed the overall identity of human-altered habitats. It describes the shift of human populations migrating from rural areas, filling up cities and their environment. In urban areas, natural flora and fauna have become a secondary factor. As a result, urban habitats are characterized by many extreme anthropogenic factors such as elevated chemical levels, transformed landscape elements, pollution patches, and disturbance sources from the enriched population (Marzluff et al. 2001, Devictor et al. 2007). The alteration of habitats offers different food-availability, and in most cases, a specialized predator presence. As a consequence, qualitative differences can be observed among urban and non-urban habitats in interspecific interactions such as predator-prey relationships (Chace \& Walsh 2006). Most of the species disappeared from cities, but some genera were successfully adapted to the changes in habitats. Urbanization acts as an environmental filter: as urbanization increases, bird species with similar ecological needs come forward (Croci et al. 2008, Meffert \& Dziock 2013, Sol et al. 2014). The urban fauna has a strictly narrowed spectrum, compared to a natural habitat. (Rosenberg et al. 1987, Mills et al. 1989, Jokimäki \& Suhonen 1993, O'Connell et al. 2000, Ives et al. 2016, Morelli et al. 2016). Firstly, during urbanization, granivorous, insectivorous, and in air hunting insectivorous bird species were known to be more common (Emlen 1974, Allen \& O'Conner 2000), but recent studies showed, that omnivorous and seed eater species are the most common in cities, because they gain the most profit in urban habitats. On the other hand, birds that usually feed on insects are the most vulnerable to the negative effects of urbanization, so they are more abundant in rural and suburban regions (Máthé \& Batáry 2015). In nesting ecology, permanent nesting has an advantage against wandering birds (Allen \& O'Conner 2000, Kluza et al. 2000, Poague et al. 2000). The studies coping deeper with the effect of urbanization revealed that the density and diversity of birds concentrate in the peak on less disturbed, mostly suburban, or boundary zones (Jokimäki \& Suhonen 1993, Blair 1999). As the urbanization effect grows, the less adaptive birds disappear from urban ecosystems (Blair 2001). A very impressive example for successful colonization of urban areas in Hungary are the corvid species, such as Hooded Crows Corvus cornix (Kövér et al. 2015), Ravens Corvus corax (Bagyura et al. 2017) or Jackdaws Corvus monedula, which are either presented in urban and agricultural or natural habitats (Meyrier et al. 2017). As a spontaneous expansion of the Eurasian Collared Dove Streptopelia decaocto has led to following urban habitats and a strong connection to human presence, so the urbanizing predators are assumed as a high risk for this species. In parallel, the presence of Wood Pigeons Columba palumbus in urban areas has also increased in the past decades (Bankovics 2001). According to formerly presented publications, the main reasons for regressing trends of Eurasian Collared Doves in Hungary are the lack of food sources, the higher level of built-up areas in the city, the competition of other species (Feral Pigeon Columba livia domestica), and the increasing level of nest predators (Juhász 1990).

Bird communities in Debrecen are highly affected by the increasing population of Hooded Crows, which is the primary nest predator of urbanized bird species, such as Eurasian Collared Doves and Wood Pigeons. Other corvids, like Magpies Pica pica, can also destroy urban bird nests. This species has also increased in urban habitats (Jokimäki et al. 2016). 


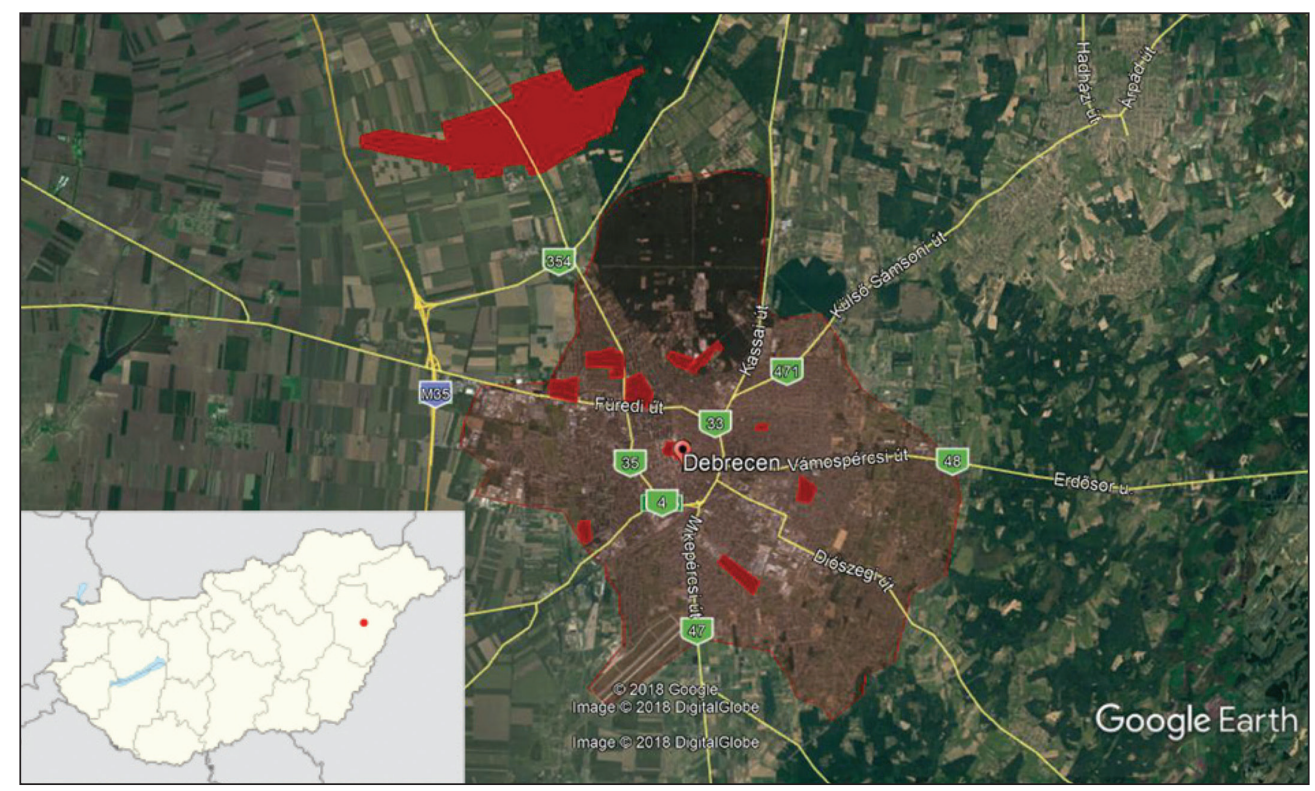

Figure 1. Map of sampling sites

1. ábra A vizsgált mintaterületek térképe

In this study, our main goals were to identify the possible connection between populations of two urbanized Columbidae species and their potential urban nest predator the Hooded Crow, which has been increased in numbers in the past ten years (Kövér et al. 2015). Since corvids prefer evergreen vegetation, the coniferous trees were also taken into consideration as an influential factor. In our opinion, Eurasian Collared Doves were migrated from disturbed areas to outskirts, since a higher abundance was discovered near Debrecen.

\section{Materials and methods}

\section{Study areas}

Our survey was carried out in Debrecen, Hungary, because the most data of population dynamics were presented from this city from the early ' $80 \mathrm{~s}$. We assigned 10 sampling sites (172.08 ha) in the city and 6 more sites in Józsa (458.1 ha), which was formerly an individual village (Figure 1). The 10 sites were chosen to represent the diversity of habitat types in the whole city. The area of Józsa was entirely recorded. Observations were performed from 2016-2020 with a year of pause in 2017.

\section{Data collection}

In each year between 21-27 July, all sites were recorded. Daily observations were carried out from 7:00 am to 12:00 am. During data collection, all sites were covered by foot the 
following factors were recorded: the size of the study area (ha), density of Eurasian Collared Dove density of Wood Pigeon, density of Hooded Crows as the primary nest predator (densities were calculated to individual/10 ha). Tree densities were calculated from the observed individuals and the area of the sampling site. Records were summarized and the mean population density was calculated. In Józsa we used Pielowski's line estimation method (Pielowski 1969). The street network was used as stripes with a 50 metres width to both sides (100 m bandwidth) for bird density surveys in the entire village. Birds flying forwards and inside the line were not taken into the summary. The transect length was estimated from city maps, then during the field work a GPS based pedometer was used for exact values. Tree height was estimated with Christen's tree height measuring device, then data was validated by laser distance meter. Tree densities were calculated from observed trees and the area of each site. In Debrecen, the overall area of each site was observed, and all birds and trees were recorded within the area, then densities were calculated.

From the records, a standard density was calculated, the average tree height was also evaluated from field records. Control measurements by Pielowski (1969) revealed that the method usually overestimates brown hare populations, so during the evaluation of Pielowski's estimation, a $20 \%$ correction was used in our research.

Habitat preference was computed by Duncan's index of habitat preference: $\mathrm{HPI}=(\mathrm{Oh} / \mathrm{Ot}) /$ $(\mathrm{Ah} / \mathrm{At})$ with 'Oh' being observations in habitat ' $\mathrm{h}$ ', 'Ot' is all observations in all habitats, 'Ah' is area covered by habitat ' $h$ ' and 'At' is the total area. This index uses a top-open scale in which 0 indicates avoidance, between 0 and 1 indicates preference, and above 1 it indicates overuse, e.g. a value of 2.00 represents $200 \%$ of habitat overuse.

\section{Statistical analysis}

After the data was organized, Mann-Whittney U and Kruskal-Wallis tests were used to determine any difference in population densities of the observed bird species between observation years and cities. Then, data was grouped by cities, and Pearson's correlation was computed to reveal if higher coniferous tree species density results higher population densities. Since the general appearance and branch structure of each species are different, these species were correlated to the three observed species individually. For evaluation, SPSS 25.0 software was used. Due to numerous correlations, False Discovery Rate was used to check significance values.

\section{Results}

\section{Differences between populations}

Since the Kolmogorov-Smirnov test revealed that none of the observation data have a normal distribution at $95 \%$ confidence interval, nonparametric tests were used.

Eurasian Collared Dove density was significantly higher (Mann-Whitney U: 2.457, $\mathrm{P}=0.014, \mathrm{n}=16$ sites) and Hooded Crow was significantly lower in Józsa (Mann-Whitney 


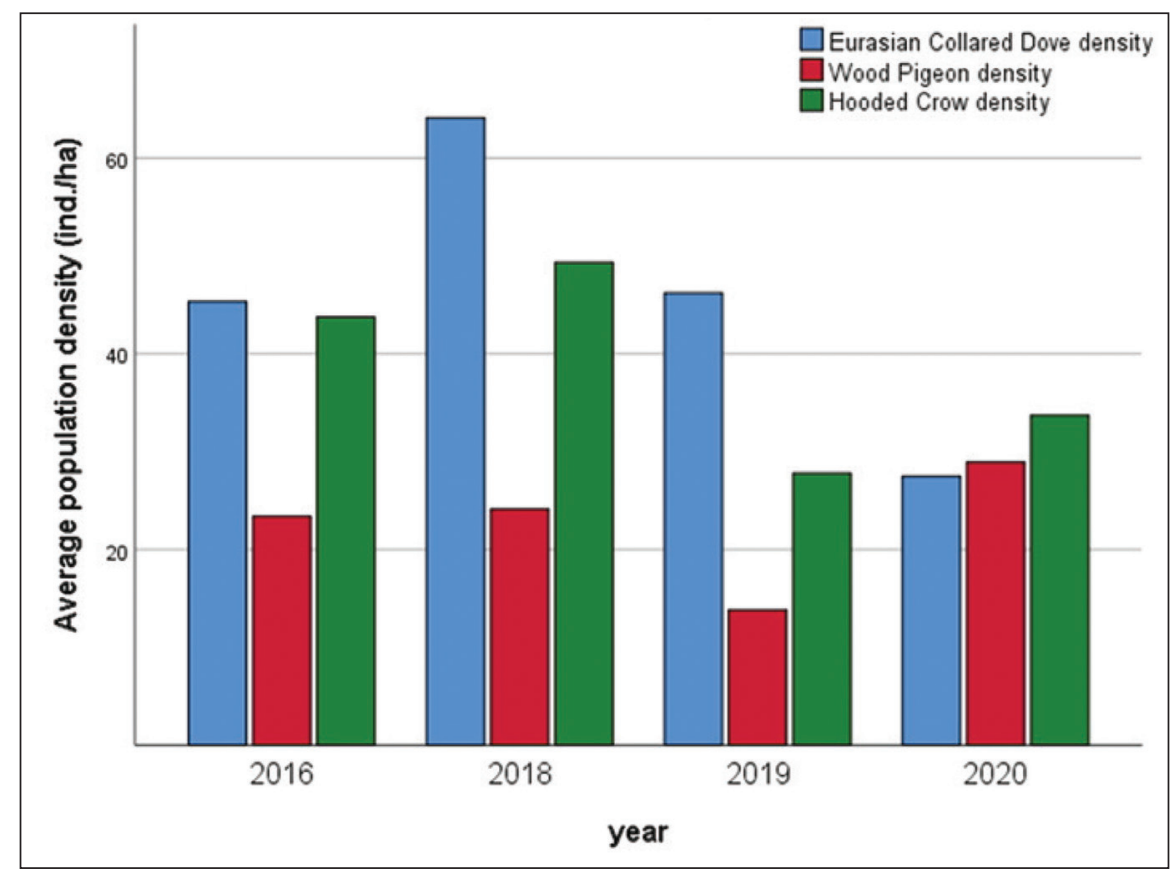

Figure 2. Population dynamics of the three observed species in Debrecen 2. ábra A három megfigyelt faj populációdinamikája Debrecenben

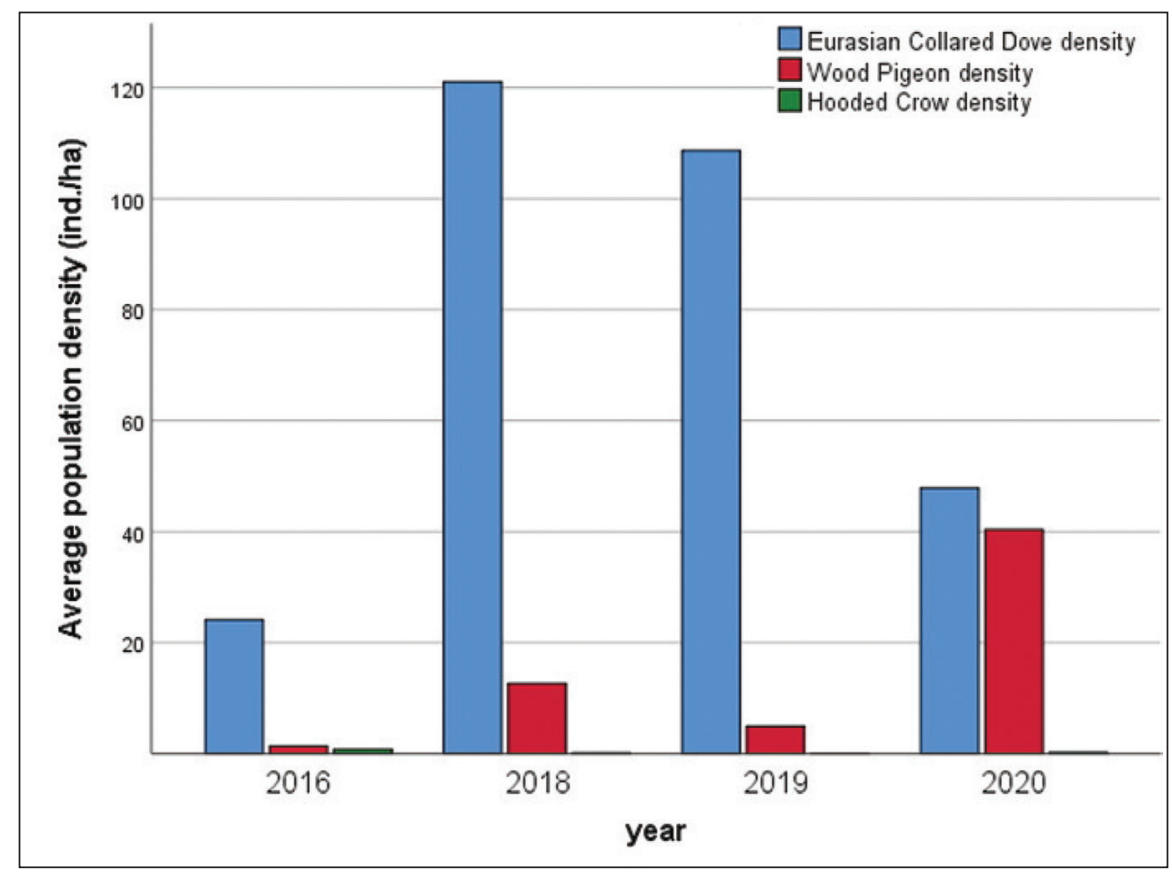

Figure 3. Population dynamics of the three observed species in Józsa

3. ábra A három megfigyelt faj populációdinamikája Józsán 


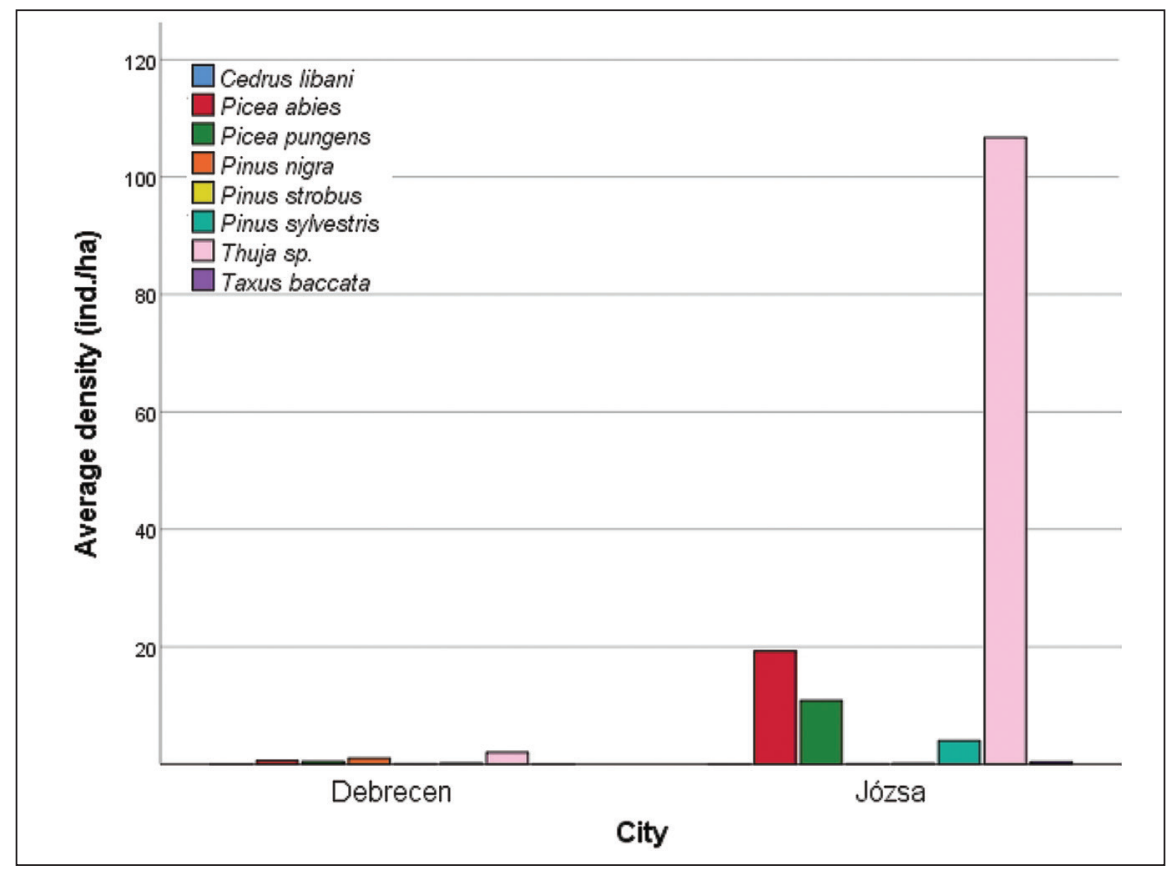

Figure 4. Coniferous tree densities in study areas

4. ábra Túlevelü fák állománysűrűsége a vizsgált területeken

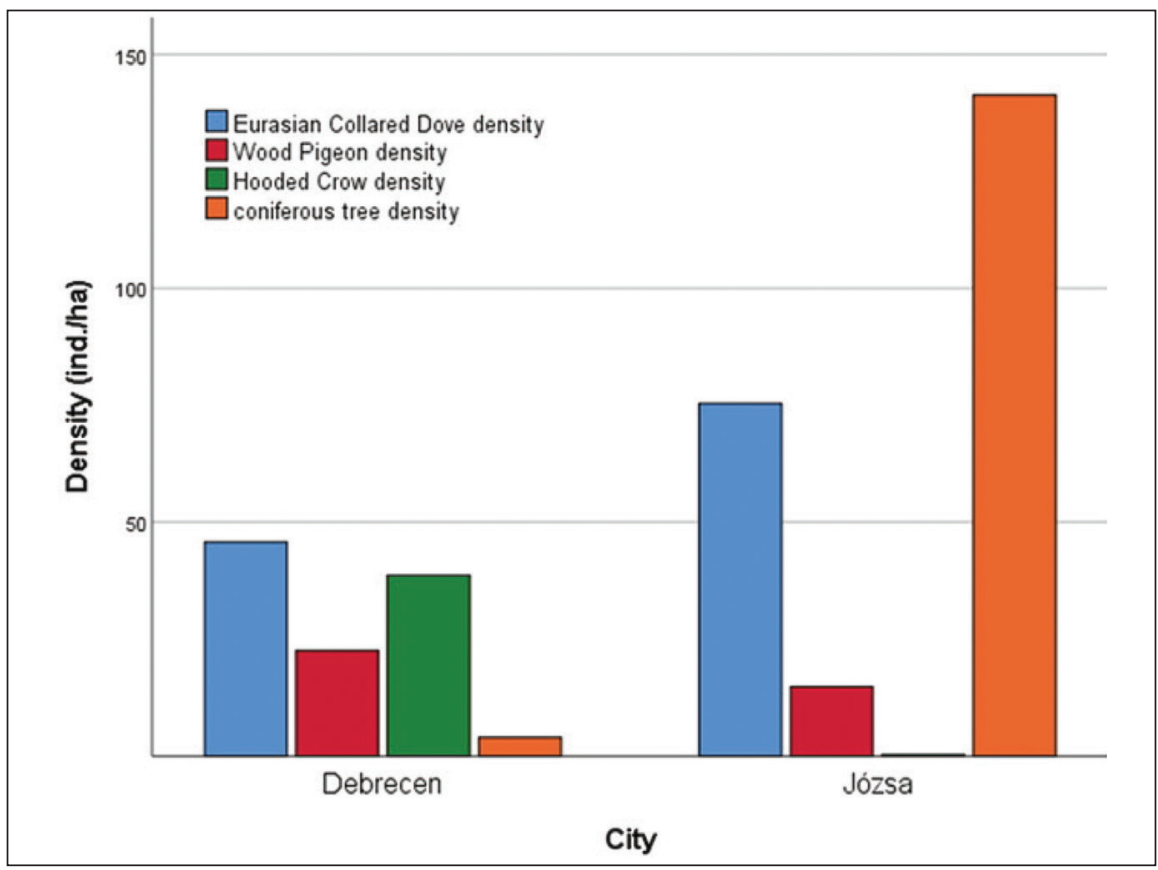

Figure 5. Population densities of the three species with overall coniferous tree density values 5. ábra A három vizsgált faj és az összes tülevelü fa denzitásértékei 
$\mathrm{U}:-5.585, \mathrm{P}<0.01, \mathrm{n}=16$ sites) than Debrecen. During the evaluation of temporal trends, no significant differences were found in Debrecen, meanwhile in Józsa the Eurasian Collared Dove population was higher in 2018, then fell back continuously until 2020 (Kruskal-Wallis: $12.604, \mathrm{P}=0.006, \mathrm{n}=24$ counts at six sites in the four years). Simultaneously, Wood Pigeons have gained ground and began to rise in 2020 (Kruskal-Wallis: 16.049, $\mathrm{P}=0.001, \mathrm{n}=$ 24 counts at six sites in the four years) (Figure 3).

\section{Tree availability of sampling sites}

The two settlements showed great difference in species abundance and species richness of coniferous trees. Since Józsa is an emerging suburban residential area, the proportion of green areas is higher. The preference of planting coniferous trees can be related to old traditions, because before the introduction of black locust (Robinia pseudo-acacia) pine tree species were used as building material. Since on plain lands wood availability was low, residents grew pine (mostly Pinus sylvestris) trees on their land to ensure their wood supply. Later, citizens of Debrecen moved out to this town, and a new suburban community grew out. The most common decorative tree species were Picea abies, Picea pungens and Thuja sp., which can be clearly seen on Figure 4. The overall density of coniferous tree species are significantly higher in Józsa (Mann-Whitney U: 6.674, $\mathrm{P}<0.05, \mathrm{n}=16$ ). In average tree height, there was no significant difference (Mann-Whitney $\mathrm{U}: 13.0, \mathrm{p}=0.073, \mathrm{n}=16)$.

\section{Correlations}

During the examination of possible correlations between species and coniferous tree species availability, numerous significant correlations were found. In Debrecen, Eurasian Collared Dove was correlated to Thuja sp. (cor.: 0.656, $\mathrm{p}=0.04, \mathrm{n}=10$ ), Hooded Crow was correlated with Pinus nigra (cor.: 0.760, $\mathrm{p}=0.011, \mathrm{n}=10$ ) and Wood Pigeons (cor.: 0.681, $\mathrm{p}=0,030, \mathrm{n}=10)$. In Józsa, Eurasian Collared Doves density correlated to Pinus strobus (cor.: 0.909, $\mathrm{p}=0.012, \mathrm{n}=6$ ), so did the Hooded Crows (cor.: 0,904, $\mathrm{p}=0.013, \mathrm{n}=6$ ), and the two species also correlated with each other (cor:: 0.913, $\mathrm{p}=0.011, \mathrm{n}=6$ ). All $\mathrm{p}$-values were calculated with FDR correction.

The dependence of Eurasian Collared Doves to coniferous trees is presumable from tree availability and correlations. In Debrecen, preferred tree species availability is lower, such as Collared Dove density in comparison to Józsa, where a greater amount of preferred tree individuals are available, letting the doves nest more freely. In addition, the lack of nest predator presence could increase hatching success (Figure 5).

\section{Habitat preference}

From the values in Table 1, it can be assumed that Eurasian Collared Doves prefer various urban parks, suburban habitats and flats closer to the city limits in Debrecen. The abundant food provided by the Debrecen Zoo also showed higher preference values, however, 
it was the second most preferred habitat by the hooded crows. The habitat preference of the Wood Pigeon was outstanding in the examined habitats in Debrecen, in the habitats with higher wood cover, the closed, downtown area was the least preferred by the examined individuals. Hooded Crow preferred habitats sparsely overgrown with trees in the northern part of the city.

In Józsa, due to the continuous and abundant food base and the avoidance behaviour of Hooded Crows, the HPI value of the Eurasian Collared Doves showed multiple overuse. The good positioning of the settlement and the large proportion of the surrounding agricultural areas are able to serve the food needs of the species. Where the surrounding area was less favourable, the species preference index was lower. The known nesting sites of the Wood Pigeon in the open area, e.g. the gallery forests, are underrepresented in these sample areas, so they are characterized by lower, but more balanced, preference values due to solitary nesting.

Table 1. Summary of HPI values on research sites

1. táblázat A vizsgált fajok HPI értékei a mintaterületeken

\begin{tabular}{|c|c|c|c|c|}
\hline \multirow[b]{2}{*}{ No. } & \multirow[b]{2}{*}{ City /Habitat type } & \multicolumn{3}{|c|}{ Habitat Preference Index (HPI) } \\
\hline & & $\begin{array}{c}\text { Eurasian } \\
\text { Collared Dove }\end{array}$ & $\begin{array}{l}\text { Wood } \\
\text { Pigeon }\end{array}$ & $\begin{array}{l}\text { Hooded } \\
\text { Crow }\end{array}$ \\
\hline \multicolumn{5}{|c|}{ Debrecen } \\
\hline 1 & Campus of the institution & 0.490 & 0.512 & 0.445 \\
\hline 2 & Nagyerdő - Closed forest area & 0.068 & 1.301 & 0.191 \\
\hline 3 & Debrecen Zoo - park area & 1.118 & 1.118 & 0.266 \\
\hline 4 & Rural area with gallery forest & 0.142 & 1.208 & 0.079 \\
\hline 5 & Flats in city centre & 0.343 & 0.098 & 0.053 \\
\hline 6 & Downtown park and its environment & 2.833 & 1.594 & 0.161 \\
\hline 7 & City park - with direct connection to residentials & 3.606 & 0.314 & 0.044 \\
\hline 8 & Flats in rural area & 6.326 & 1.265 & 0.088 \\
\hline 9 & Industrial area & 0.435 & 0.338 & 0.020 \\
\hline 10 & Residential area & 1.954 & 0.781 & 0.087 \\
\hline \multicolumn{5}{|c|}{ Józsa } \\
\hline 11 & Residential area - linked with agricultural land & 2.091 & 0.061 & 0.014 \\
\hline 12 & Residential area - linked with agricultural land & 4.124 & 0.313 & 0.000 \\
\hline 13 & Residential area - central area & 3.901 & 0.246 & 0.009 \\
\hline 14 & Residential area - linked with agricultural land & 3.116 & 0.292 & 0.015 \\
\hline 15 & Residential area - linked with grasslands & 1.777 & 0.211 & 0.000 \\
\hline 16 & Residential area - linked with closed forest area & 2.032 & 0.296 & 0.000 \\
\hline
\end{tabular}




\section{Discussion}

\section{Changes in bird communities of Debrecen}

During our research, we found that the spatial distribution Eurasian Collared Doves population of Debrecen has changed from highly-altered habitats to residential areas in comparison to formerly published data (Table 2).

Columbidae and Corvidae are common species that are easy to identify and monitor, so they are an easy example to track down the changes in urban habitats and the response of urban bird communities. In our case, the expansive forthcoming of Hooded Crows in urban environment (Kövér et al. 2015) and the decreasing of food sources, such as the bankrupt of mills in the city led to the decrease of Eurasian Collared Doves. Debrecen's biggest mill facility was destroyed by retreating German soldiers in 1944 (Szücs 1978). Though, the mill was closed, its grain storage was operational until 1998. This storage was open on top to subserve ventilation, so a stable food source was given to granivorous birds in the city. For further city developments, it has to be taken into consideration that the size of the urbanized area is a key factor to improve ecosystem health and human interactions with nature (Garaffa et al. 2009), so the high proportion of green areas in the city is necessary to maintain the diversity of urban bird communities.

\section{The importance of tree availability}

In our research, we found that the density of Eurasian Collared Doves can be linked to the availability of coniferous trees. In North America, Mourning Doves (Zenaida macroura) prefer red pine (Pinus resinosa) and Norway spruce (Picea abies), and habitat types such as the conifer and medium shrub categories, however, white pine (Pinus strobus) and Scotch pine (Pinus sylvestris) were not used (Caldwell 1964). As a result, we assume that in elevated levels of predator abundance, so was in Debrecen, doves seek the hideouts provided by coniferous trees. Moreover, if no threat is visible, doves nest freely without any selection for tree species. 
In Scotland, Hooded Crows prefer higher coniferous trees afar from human presence (McIvor \& Healy 2017), meanwhile in Italy Carrion Crows (Corvus corone) - the close relative of Hooded Crow - prefer open trees as nesting sites (Vignoli et al. 2013). It is not uncommon that dove species also prefer pine tree species as nesting sites. Taking this data into consideration, since Hooded Crows seem to be more sensitive to human disturbance, they avoid the area of Józsa, resulting a relaxed environment.

There are factors that were not recorded during this study like the availability of food and water sources, noise and light pollution, level of human presence. These can also modify the overall environmental conditions. The village-like structure of Józsa has advantageous conditions like animal breeding, high-percentage of agricultural lands in the neighbouring areas, or the lower level of human presence. Habitat preference values approved that this area plays a prominent role in local dove populations. Meanwhile in "classic' urban circumstances, doves prefer areas that have a stable food source, and low presence of predators. Wood Pigeons seem to prefer areas with similar tree structure that is presented outside the city.

\section{Does overurbanization degrade bird communities?}

In South-eastern Mexico, a study showed that the status of bird communities varies along land-uses, as a representative of urbanization gradient. Only a few generalist species were present in areas with commercial components and evenness was higher in green areas. As urbanization increased bird abundances increased with lower species richness. These descriptive values were also sensible to site-specific habitat characteristics (Ortega-Álvarez \& MacGregor-Fors 2009).

We concluded that urban planning can also promote avifauna abundance in the city centre by varying the heights of buildings in urban renewal projects rather than clustering buildings of similar height, or by focusing on the spatial configuration of green spaces (especially their proximity) rather than their area.

In Italy a large-scale sampling was carried out on an urban gradient, where Eurasian Collared Doves showed no connection to the specified habitat types during nest site selection. This result ensures that nesting is connected to tree species rather than urban habitat types (Vignoli et al. 2013). In our research, doves showed higher preference values to suburban and residential areas. The multiple overuse of Józsa can be related to the high proportion of agricultural lands that provides a huge amount of food. In the city centre, the lack of food results lower population levels, which can clarify the changes between urban habitat types.

A research carried out in Belarus showed that Wood Pigeons prefer deciduous trees over coniferous (Sakhvon \& Kövér 2020), so the further urbanization processes are expected in Hungary and all over Europe to the northern taiga as a spread limit.

However, coniferous tree density and average tree height do affect the structure of urban bird communities. The landscape changing effects of urbanization is a quite fresh phenomenon, not all of its relationships are explored. In this study, we could set up a line of habitat preference of prey and predator species with a special focus on coniferous tree species. 
Our results show that there is no overlap in coniferous tree preferences along these three species. Columbidae seek more cover to hide their nest, but Hooded Crows stand alone as predators in cities, so the density of shrubs affects them less. But changes in habitats, such as monodominance of a single tree in urban environment can cause an unexpected tension, so these species can become competitors on nesting trees.

\section{Acknowledgements}

The publication is supported by the EFOP-3.6.3-VEKOP-16-2017-00008 project. The project is co-financed by the European Union and the European Social Fund.

\section{References}

Allen, A. P. \& O'Conner, R. J. 2000. Hierarchical correlates of bird assemblage structure on Northeastern USA lakes. - Environmental Monitoring Assessment 62(1): 15-35. DOI: 10.1023/A:1006244932033

Bagyura, J., Fidlóczky, J., Schwartz, V. \& Tóth, L. 2017. Interesting breeding cases of the Raven (Corvus corax) in Hungary. - Ornis Hungarica 25(1): 39-43. DOI: 10.1515/orhu-2017-0003

Bankovics, A. 2001. Status of wild Pigeons and Doves in Hungary. - Naturzale 16: 61-70.

Bersier, L. F. \& Meyer, D. R. 1994. Bird assemblages in mosaic forests - the relative importance of vegetation structure and floristic composition along the successional gradient. - Acta Oecologica 15: 561-576.

Bersier, L. F. \& Meyer, D. R. 1995. Relationships between bird assemblages, vegetation structure, and floristic composition of mosaic patches in riparian forests. - Revue d' Ecologie-la Terre et la Vie 50: 15-33.

Blair, R. B. 1999. Birds and butterflies along an urban gradient: surrogate taxa for assessing biodiversity? - Ecological Applications 9(1): 164-170. DOI: 10.2307/2641176

Blair, R. B. 2001. Birds and butterflies along urban gradients in two ecoregions of the United States: is urbanization creating a homogeneous fauna? - In: Lockwood, J. L. \& McKinney, M. L. (eds.) Biotic Homogenization: The Loss of Diversity Through Invasion and Extinction. - Kluwer Academic Publishers, Boston, MA. pp. 33-56.

Caldwell, L. D. 1964. Dove production and nest site selection in Southern Michigan. - The Journal of Wildlife Management 28(4): 732-738. DOI: 10.2307/3798788

Chace, J. F. \& Walsh, J. J. 2006. Urban effects on native avifauna: a review. - Landscape and Urban Planning 74(1): 46-69. DOI: 10.1016/j.landurbplan.2004.08.007

Croci, S., Butet, A. \& Clergeau, P. 2008. Does urbanization filter birds on the basis of their biological traits? Condor 110(2): 223-240. DOI: 10.1525/cond.2008.8409

Devictor, V., Julliard, R., Couvet, D., Lee, A. \& Jiguet, F. 2007. Functional homogenization effect of urbanization on bird communities. - Conservation Biology 21(3): 741-751. DOI: 10.1111/j.1523-1739.2007.00671.x

Emlen, J. T. 1974. An urban bird community in Tucson, Arizona: derivation, structure, regulation. - Condor 76(2): 184-197. DOI: $10.2307 / 1366729$

Garaffa, P. I., Filloy, J. \& Bellocq, M. I. 2009. Bird community responses along urban-rural gradients: Does the size of the urbanized area matter? - Landscape and Urban Planning 90(1-2): 33-41. DOI: 10.1016/j.landurbplan.2008.10.004

Ives, C. D., Lentini, P. E., Threlfall, C. G., Ikin, K., Shanahan, D. F., Garrard, G. E., Bekessy, S. A., Fuller, R. A., Mumaw, L., Rayner, L., Rowe, R., Valentine, L. E. \& Kendal, D. 2016. Cities are hotspots for threatened species. - Global Ecology and Biogeography 25(1): 117-126. DOI: 10.1111/geb.12404

Jokimäki, J. \& Suhonen, J. 1993. Effects of urbanization on the breeding bird species richness in Finland: a biogeographical comparison. - Ornis Fennica 70: 71-77.

Jokimäki, J., Suhonen, J., Vuorisalo, T., Kövér, L. \& Kaisanlahti-Jokimäki, M-L. 2017. Urbanization and nestsite selection of the Black-billed Magpie (Pica pica) populations in two Finnish cities: From a persecuted species to an urban exploiter. - Landscape and Urban Planning 157: 577-585. DOI: 10.1016/j.landurbplan.2016.08.001. 
Juhász, L. 1990. A balkáni gerle állományának változása 1980-1990 között hazánk néhány mezőgazdasági régiójában [Population changes in the population on Eurasian Collared Doves between 1980-1990 in some of the agricultural lands of Hungary]. - Debreceni Agrártudományi Egyetem Tudományos Közleményei 1990: 153-169. (in Hungarian)

Kluza, D. A., Griffin, C. R. \& DeGraaf, R. M. 2000. Housing developments in rural New England: effects on forest birds. - Animal Conservation 3(1): 15-26. DOI: 10.1111/j.1469-1795.2000.tb00083.x

Kövér, L., Gyüre, P., Balogh, P., Huettmann, F., Lengyel, Sz. \& Juhász, L. 2015. Recent colonization and nest site selection of the Hooded Crow (Corvus corone cornix L.) in an urban environment. - Landscape and Urban Planning 133: 78-86. DOI: 10.1016/j.landurbplan.2014.09.008

Marzluff, J. M., Bowman, R. \& Donelly, R. 2001. A historical perspective on urban bird research: trend, term, and approaches. - In: Marzluff, J. M., Bowman, R. \& Donelly, R. (eds.) Avian Ecology and Conservation in an Urbanizing World. - Kluwer Academic Publishers, MA. pp. 1-17.

Máthé, O. \& Batáry, P. 2015. Insectivorous and open-cup nester bird species suffer the most from urbanization. Bird Study 62(1): 78-86. DOI: 10.1080/00063657.2014.1000262

McIvor, G. E. \& Healy, S. D. 2017. Nest site selection and patterns of nest re-use in the Hooded Crow Corvus cornix. - Bird Study 64(3): 1-12. DOI: 10.1080/00063657.2017.1364220

Meffert, P. J. \& Dziock, F. 2013. The influence of urbanisation on diversity and trait composition of birds. - Landscape Ecology 28: 943-957. DOI: 10.1007/s10980-013-9867-z

Meyrier, E., Jenni, L., Bötsch, Y., Strebel, S., Erne, B. \& Tablado, Z. 2017. Happy to breed in the city? Urban food resources limit reproductive output in Western Jackdaws. - Ecology and Evolution 7(5): 1363-1374. DOI: $10.1002 /$ ece 3.2733

Mills, G. S., Dunning, Jr., J. B. \& Bates, J. M. 1989. Effects of urbanization on breeding bird community structure in southwestern desert habitats. - Condor 91(2): 416-428. DOI: 10.2307/1368320

Morelli, F., Benedetti, Y., Ibanez-Alamo, J. D., Jokimäki, J., Mänd, R., Tryjanowski, P. \& Møller, A. P. 2016. Evidence of evolutionary homogenization of bird communities in urban environments across Europe. - Global Ecology and Biogeography 25(11): 1284-1293. DOI: 10.1111/geb.12486

O’Connell, T. J., Jackson, L. E. \& Brooks, R. P. 2000. Bird guilds as indicators of ecological condition in the central Appalachians. - Ecological Applications 10(6): 1706-1721. DOI: 10.1890/1051-0761(2000)010 [1706:BGAIOE]2.0.CO;2

Poague, K. L., Johnson, R. J. \& Young, L. J. 2000. Bird use of rural and urban converted railroad rights-of-way in southeast Nebraska. - Wildlife Social Biology 28(4): 852-864. DOI: 10.2307/3783840

Pielowski, Z. 1969. Belt assessment as a reliable method of determining the numbers of Hares. - Acta Theriologica 14(9): 133-140.

Rosenberg, K. V., Terrill, S. B. \& Rosenberg, G. H. 1987. Value of suburban habitats to desert riparian birds. Wilson Bulletin 99(4): 642-654.

Sakhvon, V. \& Kövér, L. 2020. Distribution and habitat preferences of the urban Woodpigeon (Columba palumbus) in the north-eastern breeding range in Belarus. - Landscape and Urban Planning 201: 103846. DOI: 10.1016/j.landurbplan.2020.103846

Sol, D., González-Lagos, C., Moreira, D., Maspons, J. \& Lapiedra, O. 2014. Urbanisation tolerance and the loss of avian diversity. - Ecology Letters 17(8): 942-950. DOI: 10.1111/ele.12297

Szűcs, E. 1978. A debreceni István gőzmalom története [History of ‘István' steam mill in Debrecen]. - Hajdú-Bihar Megyei Levéltár Közleményei 12. (in Hungarian)

Vignoli, L., Scirè, S. \& Bologna, M. A. 2013. Rural-urban gradient and land use in a millenary metropolis: how urbanization affects avian functional groups and the role of old villas in bird assemblage patterning. - Web Ecology 13(1): 49-67. DOI: 10.5194/we-13-49-2013 